$\mathrm{DOE} / \mathrm{BC} / 14936-13$

(OSTI ID: 14432)

\title{
APPLICATION OF ADVANCED RESERVOIR CHARACTERIZATION, SIMULATION, AND PRODUCTION OPTIMIZATION STRATEGIES TO MAXIMIZE RECOVERY IN SLOPE AND BASIN CLASTIC RESERVOIRS, WEST TEXAS (DELAWARE BASIN)
}

Quarterly Technical Progress Report

July 1, 1998-September 30, 1998

By

Shirley P: Dutton

Report Issue Date: October 23, 1998

Performed Under Contract No. DE-FC22-95BC14936

Bureau of Economic Geology University of Texas @ Austin

Austin, Texas 


\section{DISCLAIMER}

This report was prepared as an account of work sponsored by an agency of the United States Government. Neither the United States Government nor any agency thereof, nor any of their employees, makes any warranty, expressed or implied, or assumes any legal Iiability or responsibility for the accuracy, completeness, or usefulness of any information, apparatus, product, or process disclosed, or represents that its use would not infringe privately owned rights. Reference herein to any specific commercial product, process, or service by trade name, trademark, manufacturer, or otherwise does not necessarily constitute or imply its endorsement, recommendation, or favoring by the United States Government or any agency thereof. The views and opinions of authors expressed herein do not necessarily state or reflect those of the United States Government.

This report has been reproduced directly from the best available copy. 


\section{DISCLAIMER}

Portions of this document may be illegible in electronic image products. Images are produced from the best available original document. 
$\mathrm{DOE} / \mathrm{BC} / 14936-13$

Distribution Category UC-122

Application of Advanced Reservoir Characterization, Simulation, and Production Optimization Strategies to Maximize Recovery in Slope and Basin Clastic Reservoirs, West Texas (Delaware Basin)

\author{
By \\ Shirley P. Dutton
}

November 1999

Work Performed Under Contract No. DE-FC22-95BC14936

\author{
Prepared for \\ U.S. Department of Energy \\ Assistant Secretary for Fossil Energy \\ Dan Ferguson, Project Manager \\ National Petroleum Technology Office \\ P.O. Box 3628 \\ Tulsa, OK 74101
}

Prepared by

Bureau of Economic Geology

University of Texas @ Austin

University Station

P.O. Box X

Austin, TX 78713 
Title:

Cooperative Agreement No.:

Institution:

Date of Report:

Award Date:

Anticipated Completion Date for this Budget:

Government Award for this Budget Period:

Program Manager:

Principal Investigator:

Contracting Officer's Representative:

Reporting Period:
APPLICATION OF ADVANCED RESERVOIR

CHARACTERIZATION, SIMULATION, AND

PRODUCTION OPTIMIZATION STRATEGIES TO

MAXIMIZE RECOVERY IN SLOPE AND BASIN

CLASTIC RESERVOIRS, WEST TEXAS

(DELAWARE BASIN)

DE-FC22-95BC14936-13

Bureau of Economic Geology

The University of Texas at Austin

University Station, Box $X$

Austin, Texas 78713-7508

October 23, 1998

March 31, 1995

June 30, 1999

$\$ 1,248,033$

Daniel Ferguson

Shirley P. Dutton

Daniel Ferguson

July 1, 1998 - September 30, 1998 


\section{OBJECTIVES}

The objective of this Class 3 project is to demonstrate that detailed reservoir characterization of slope and basin clastic reservoirs in sandstones of the Delaware Mountain Group in the Delaware Basin of West Texas and New Mexico is a cost effective way to recover a higher percentage of the original oil in place through strategic placement of infill wells and geologically based field development. Project objectives are divided into two main phases. The original objectives of the reservoir-characterization phase of the project were (1) to provide a detailed understanding of the architecture and heterogeneity of two representative fields of the Delaware Mountain Group, Geraldine Ford and Ford West, which produce from the Bell Canyon and Cherry Canyon Formations, respectively, (2) to chose a demonstration area in one of the fields, and (3) to simulate a $\mathrm{CO}_{2}$ flood in the demonstration area.

After the reservoir characterization and simulation of an area at the northern end of the Ford Geraldine unit were completed, the industry partner decided not to proceed to Phase 2. installation of a $\mathrm{CO}_{2}$ flood in the demonstration area. A new industry partner, Orla Petco, Inc., will participate in the remainder of the project, which includes a field demonstration to be conducted in the East Ford unit. The East Ford unit is immediately adjacent to the Ford Geraldine unit and produces from the same Ramsey sandstone channel. The reservoir characterization phase of the project has been expanded to include East Ford unit. This additional reservoircharacterization task provides an excellent opportunity to test the transferability of the geologic model and log-interpretation methods developed during reservoir characterization of the Ford Geraldine unit to another Delaware sandstone field.

The objectives of the implementation phase of the project remain the same, to (1) apply the knowledge gained from reservoir characterization and simulation studies to increase recovery from a demonstration area, (2) demonstrate that economically significant unrecovered oil can be recovered by a $\mathrm{CO}_{2}$ flood of the demonstration area, and (3) test the accuracy of reservoir characterization and flow simulation as predictive tools in resource preservation of mature fields. The goal is to develop a geologically designed $\mathrm{CO}_{2}$ flood and well-completion program in a representative Delaware Sandstone field that can serve as a model for other fields in the play. Through technology transfer, the knowledge gained in this study can be applied to increase production from more than 100 other Delaware Mountain Group reservoirs.

\section{SUMMARY OF TECHNICAL PROGRESS}

\section{Reservoir Characterization}

Reservoir characterization of the East Ford unit began this quarter with data collection and data base construction. Logs from the East Ford unit (45) and two adjacent dry holes were copied at the Orla Petco office in Midland. Corresponding well-location coordinates were obtained from a data base acquired earlier in the project. A total of 98 log curves have been digitized in LAS format and loaded into a Landmark Openworks ${ }^{\mathrm{TM}}$ data base. A base map showing well locations was created using Landmark software.

Tops for the reservoir sandstones and adjacent nonreservoir intervals have been picked on all logs in the East Ford unit. The Ramsey sandstone interval at the East Ford unit is divided into upper and lower sandstones by a laterally persistent siltstone (SH1). The upper sandstone is equivalent to the Ramsey 2 sandstone of the Ford Geraldine unit, and the lower sandstone correlates to the Ramsey 1 sandstone. The tops, elevation datum, total depth, API number, and latitude and longitude for each well have been entered into the OpenWorks ${ }^{\mathrm{TM}}$ data base. 
Preliminary structure and isopach maps and cross sections have been used to locate problems in the data base and log digitization.

Core-analysis data from 11 East Ford wells (620 analyses) were entered into a spread sheet and sorted by stratigraphic interval. Core-measured porosity in Ramsey sandstones in the East Ford unit ranges from 2.9 to 30.6 percent and permeability from 0.01 to $312 \mathrm{md}$. The average values of porosity and geometric mean permeability for each stratigraphic interval are as follows:

Porosity (percent) Permeability (md)

$\begin{array}{lcc}\text { Trap siltstone } & 14.7 & 0.60 \\ \text { Ramsey } 2 \text { sandstone } & 21.4 & 14.8 \\ \text { SH1 siltstone } & 18.0 & 2.9 \\ \text { Ramsey } 1 \text { sandstone } & 22.5 & 30.6 \\ \text { Ford siltstone } & 15.9 & 0.63\end{array}$

The porosity-permeability transform for the Ramsey sandstone in the East Ford unit developed from the core-analysis data is as follows:

$$
\text { Log permeability }(\mathrm{md})=0.14 \text { (porosity) }-1.83
$$

This equation will be used to calculate permeability from log-derived porosity values. A porosity of 13 percent corresponds to permeability of $1 \mathrm{md}$, and porosity of 17.5 percent corresponds to permeability of $5 \mathrm{md}$. Net pay will be calculated using both of these porosity values as cutoffs.

\section{Petrophysical Analysis}

The procedure for quantitative petrophysical analysis that was developed for the Ford Geraldine unit is being followed to characterize the East Ford unit (Asquith and others, 1997; Dutton and others, 1998). Core and log data will be integrated and petrophysical properties will be quantified from wireline logs; the goal is a set of maps of porosity, permeability, net pay, water saturation, porous hydrocarbon volume, and other reservoir properties across the unit. Petrophysical analysis of the Ramsey sandstone at the East Ford unit is complicated by the incomplete nature of the logging suites. Of the 45 wells in the unit, 26 penetrate the entire reservoir interval. A review of available log suites from the East Ford unit showed that 30 wells have porosity logs, but 4 of those wells have only cased-hole neutron logs. The cased-hole neutron logs will not be used for quantitative petrophysical analysis. Only 17 wells have both porosity and resistivity logs.

The gamma-ray logs in East Ford field were run in the early 1960's by several different companies at different sensitivities and thus cannot be directly compared, even though all but one of the logs was recorded in API units. All the gamma-ray logs were normalized by equations in the following form: $\quad$ Normalized $G R$ value (API units) $=m$ (old GR value) $+b$. where the slope and $y$-intercept were calculated for each log individually.

Core-log correction factors were calculated for each cored well so that core depths could be depth-shifted to log depths. A cross plot of interval transit time (ITT) versus core porosity was constructed in order to determine a log-to-core porosity transform. From this plot, a reducedmajor-axis (RMA) equation was calculated that can be used to determine porosity in wells with sonic logs. The RMA equation relating porosity and ITT is: 
Porosity $($ percent $)=0.505($ ITT $)-24.753$

In preparation for calculating water saturations $\left(S_{W}\right)$, formation-water resistivities $\left(R_{W}\right)$ were estimated across the Ford East unit from a map of formation-water salinities. Data from the East Ford unit were combined with those from the Ford Geraldine unit (Dutton and others, 1997 ) to obtain a more regional view. Values of $R_{W}$ at $75^{\circ} \mathrm{F}$ ranged from 0.10 to $0.12 \mathrm{ohm}-\mathrm{m}$.

\section{PLANNED ACTIVITIES}

A subcontract between The University of Texas at Austin and Orla Petco, Inc. is in progress and should be completed during the next quarter.

Reservoir characterization of East Ford field will continue next quarter. Isopach maps and cross sections of the reservoir sandstone bodies and bounding siltstones will be finalized, and a depositional model for East Ford field will be constructed. Petrophysical characterization will continue with the following tasks: (1) estimate volume of clay in Ramsey sandstones using the equations for gamma-ray index and $\mathrm{V}_{\mathrm{Cl}}$, (2) determine true formation resistivity ( $R_{\mathrm{t}}$ ) using the transform developed for the Ford Geraldine unit (Asquith and others, 1997), (3) calculate $\mathrm{S}_{\mathrm{W}}$ using the modified Archie equation developed previously for Delaware sandstones (Asquith and others, 1997), and (4) construct petrophysical maps for the East Ford unit.

\section{REFERENCES}

Asquith, G. B., Dutton, S. P., Cole, A. G., Razi, M., and Guzman, J. 1., 1997, Petrophysics of the Ramsey Sandstone, Ford Geraldine Unit, Reeves and Culberson Counties, Texas: West Texas Geological Society Publication No. 97-102, p. 61-69.

Dutton, S. P., Asquith, G. B., Barton, M. D., Cole, A. G., Gogas, J., Malik, M. A., Clift, S. J., and Guzman, J. I., 1997, Application of advanced reservoir characterization, simulation, and production optimization strategies to maximize recovery in slope and basin clastic reservoirs, West Texas (Delaware Basin): The University of Texas at Austin, Bureau of Economic Geology, annual report prepared for the U.S. Department of Energy, $187 \mathrm{p}$.

Dutton, S. P., Barton, M. D., Malik, M. A., Asquith, G. B., Guzman, J. I., Clift, S. J., Cole, A. G., 1998, Application of advanced reservoir characterization, simulation, and production optimization strategies to maximize recovery in slope and basin clastic reservoirs, West Texas (Delaware Basin): The University of Texas at Austin, Bureau of Economic Geology, annual report prepared for the U.S. Department of Energy, 88 p. 